\title{
JELSZAVAK ÉS KÖNYÖRTELEN KRITIKA: MARXIZMUS ÉS NEMZETKÖZI KRITIKAI GEOGRÁFIA ${ }^{1}$
}

\author{
(Of Shibboleths and Ruthless Critique: Marxism and \\ International Critical Geography)
}

\author{
NEIL SMITH
}

Kulcsszavak:

kritikai geográfia marxizmus befogadás reflexivitás kapitalistakizsákmányolás politikai harc

A kritikai geográfusok 1997-es alakuló vancouveri konferenciája világossá tette, hogy szükség van nemzetközi kritikai geográfia létrehozására, kiteljesitésére - de, hogy mi szamit kritikainak, az nagyon bizonytalanul definiált. E cikk igyekszik megragadni e kibontakozó politikai és szellemi csoport fö jellemzöit, illetve ,jelszavait". Ma a baloldal hagyomanyos tanítása a befogadásra és az önreflexivitásra buzdít. Olyan vélemény is létezik, hogy minden politikai harc egyenlö, a politikát pedig gyakran összeke. verik az etikával. A cikk vitatja ezeknek az állaspontoknak a hasznosságát a 21. századi nemzetközi kritikai geográfia kontextusában, s a marxista kritika erejének újragondolására szólit fet.

\section{Bevezetés}

A kritikai geográfia az 1990-es években jelent meg a kizsákmányolás és elnyomás legyỏzése mellett elkötelezett kutatás szétágazó vonulatai összefogásának eszközeként. A mozgalom gyökerei az 1960-as években fellángoló, széles körben elterjedt radikalizálódásig nyúlnak vissza - ez segítette világra az 1970-es években a radikális geográfiát. Az Antipode folyóirat legkorábbi számainak áttekintéséből kiviláglik a politikai célpontok sokfélesége: kapitalizmus, imperializmus, patriarchátus, fajgyủlölet, a kömyezet kifosztása, a homoszexuális férfiak és leszbikus nỏk elnyomása, a geográfia konzervatizmusa stb. Ezt az akadémiai radikalizációt továbbra is a világszerte jelentkező tiltakozó és forradalmi mozgalmak éltették, ám az 1980-as évekre a világpolitika sokkal konzervatívabb lett, és Európában, ÉszakAmerikában, Óceánia térségében és Japánban a tudományos élet radikalizmusának élét elvette az akadémiai fó áramlatba való betagozódás. A kritikai geográfia megjelenése szándékos kísérlet volt arra, hogy megállítsa ezt a jobboldali elmozdulást, és széles körü baloldali jelenlétet teremtsen a geográfiában.

Erejét mutatja, hogy ma már, kezdve a feminizmustól egészen a kulturális kutatásokig, a tudományos gondolkodás kiterjedtebb hatásai táplálják a kritikai geográfiát, amely pedig - visszahatva - vitákat generál ezeken a területeken. De egyre több a bizonyíték arra is, hogy a „kritikai geográfia” címkével megjelölt munkák kiterjedtségének igen magas ára van. A kritikai geográfiának ma sokkal világosabb, élesebb és pontosabban megfogalmazott fókuszpontot kell kialakítania. A kortárs 
Neil Smith : Jelszavak és könyörtelen kritika : Marxizmus és nemzetközi kritikai geográfia

Tér és Társadalom 17. évf. 2003/2. 37-51. p.

TÉT XVII. évf. 2003 @ 2

kritikai geográfia állandóan ismételgetett tanításai a befogadáshoz kapcsolódnak: a kirekesztés politikailag helytelen, a befogadás a helyes út. De mibe kell „,befogadni"? Az identitáspolitika, multikulturalizmus és a hozzájuk kötődő mozgalmak morális értelmezésének köszönhetően a „befogadás” formális követelmény lett, s egyre inkább hiányzik belöle a valós tartalom. Sokan vagyunk, akik nem törekszünk arra, hogy olyan politikai felépítményekbe tagozódjunk be (fogadjanak be bennünket), amelyek tovább éltetik az osztály- vagy faji, nemi vagy nemzeti különbségekben gyökerező kizsákmányolást és elnyomást, és arra sem, hogy új kormányzati rendszereket találjunk ki, amelyek érintetlenül hagyják ezeket a felépítményeket. A befogadás ideológiája a politikai küzdelmek könyörtelen leveréséhez és egyenlősítéséhez vezetett, azt sugallva, hogy egyenlöségjel vonható például a szocialista és az állatvédő mozgalmak között: mindkettöről a befogadás ugyanazon politikai nyelvén szólnak. Ám a politikai állásfoglalás lényege nem az, hogy módot ad az ilyen vagy olyan fajta moralitás mozgósítására, ahogyan a liberálisok feltételezik. A politikai elemzés célja, hogy megismerje az általunk ellenzett világ gyenge pontjait, és józanul, hideg fejjel mérje fel, milyen mozgalommal lehet megváltoztatni az ilyen világot.

A kritikai geográfiai mozgalom akkor jár sikerrel az életünk színhelyéül szolgáló kapitalista társadalmak kritikai elemzésének kifejlesztésében, ha jelenlegi kiterjedtségének megfelelö mélységủ kritikáját adja a kapitalizmusnak. Az 1980-as és az 1990-es években tapasztalt gazdasági terjeszkedést és válságokat szerte a világon a munkások - föleg a nök és a színes börüek - fizették meg vérrel, verejtékkel és könnyekkel. Az osztálypolitikában gyökerezö szocialista felkelések nem garantálnak megoldást az elnyomás minden változatára, de teret nyitnak a megszüntetésükhöz. Elemzéseinknek kezdettől fogva magukban kell foglalniuk például a fajgyülölet és a szexizmus kérdéseit, de a fürdővízzel együtt a gyereket is kiöntjük, ha közben az osztályproblémákat figyelmen kívül hagyjuk. Igaza volt Marxnak: a kapitalizmus megdöntése szolgálja legjobban a munkások érdekét, akiket az elnyomatás számos formája sújt. Bennük kell tehát megtalálnia a kritikai politikai gondolkodásnak a történelem és a földrajzi viszonyok megváltoztatására képes eröt.

Az egyetlen út az igazsághoz - mondta Marx -, minden létezö legkönyörtelenebb kritikája; s mivel a „kritika” szó melléknévi alakja a „kritikus”, azt hiszem ebben a szellemben kell törekednünk a nemzetközi kritikai geográfia megteremtésére. A kritikai geográfia ugyanúgy fegyver, mint ahogyan az igazságra való minden hivatkozás társadalmi és politikai fegyver. Eszköz, amellyel úgy vallatjuk ki a világot, hogy azzal meg is tudjuk változtatni. Ezt a kritikát a geográfia múvelésének segítségével nem a burzsoá tudományhoz vagy annak valamely ágához füződő lojalitásból gyakoroljuk. A geográfia, mint tudományág csak annyira hasznos, amennyire azok a kérdések hasznosak, amelyeket a segítségével feltehetünk, és amennyire azok a válaszok hasznosak, amelyeket a segítségével megadhatunk. S amikor már nem biztosít nekünk fórumot, ideje más „otthont” találnunk. Nekünk inkább az a véleményünk, hogy az életünknek helyet adó földrajzi tájak a társadalmi alapfeltevések megjelenítỏdései. E tájak ảnnak a kizsákmányolásnak, elnyomásnak, egyenlötlenségnek és 
Neil Smith : Jelszavak és könyörtelen kritika : Marxizmus és nemzetközi kritikai geográfia Tér és Társadalom 17. évf. 2003/2. 37-51. p.

igazságtalanságnak a látható és felkavaró „megszövegezödései”, amelyek azzá teszik a jelenkori kapitalista társadalmakat, amik. Ha tudjuk, hogyan írjuk és olvassuk tájainkat, akkor azok történeti forrásai lesznek a kapitalista kizsákmányolásnak, a fajgyülölő önkényuralomnak, a nök elnyomásának, az imperializmusnak, az etnikai és regionális kisebbségek elnyomásának és az üldöztetés sok egyéb változatának. Az így megismert földrajzi viszonyok könyörtelen kritikája ezért potenciálisan könnyebben kézzelfoghatóvá teszi ezeket az igazságtalanságokat, mint például az elvontabb filozófia, történelem vagy a politikai tudományok. Amennyire a 20. században a világ sok részén a térbeliség és a geográfiai tudás határozott eltörlése volt tapasztalható - s ez politikai szempontból messze nem ártatlan következmény, amelyre később visszatérek -, a nemzetközi kritikai geográfia megteremtésére tett erőfeszítéseink hatásai meghökkentőnek, politikai hozadékai pedig jelentösnek ígérkeznek.

A kritika azonban a kritikai geográfia törekvéseinek csak a felét jelenti. Úgy véljük, hogy az is a kritikai geográfia lényegéhez tartozik, hogy segítsen megváltoztatni a világot. A nemzetközi kritikai geográfia a legszükebb értelemben vett gyakorlati politika. Mindegy, hogy Bombayban vagy Boszniában, Sao Paulóban vagy Seattle-ben mủvelik, a kritikai geográfia semmit sem ér, ha nem részese a kizsákmányolás, zsarnokság és elnyomás elleni harcnak. Az a kritikai geográfia, amelyet nem az ilyen politikai mozgalmakban való megmártózás hajt, és amely nem törekszik elméleti és fogalmi találékonyságra, amellyel ezeket a mozgalmakat segíthetné, pusztán skolasztikus gyakorlat marad. A nemzetközi kritikai geográfia tökéletesen „tisztában van” azzal, hogy egy igazságos és egyenlőségen alapuló társadalom kialakításának hatékony része az igazságos és egyenlőségen alapuló földrajzi viszonyok megteremtése. Ha földrajzi tájaink hazudnak nekünk, mi is hazudni fogunk önmagunknak.

Ez manapság sok helyütt fontos figyelmeztetésnek számít. Vannak ma közöttünk olyanok, akiket otthon - a kizsákmányolás és az elnyomás elleni politikai mozgalmakban való részvételük miatt - letartóztatás vagy még rosszabb fenyeget. DélKorea 1988-ig katonai diktatúra volt, s egészen az utóbbi évekig még a mostanihoz hasonló tudományos konferenciát is lehetetlen lett volna itt megrendezni. Amennyire tudom, eddig még senkit sem sikerült megnyerni csoportunk számára a Kínai Népköztársaságból, Hongkongot kivéve. Ezzel szemben Angliában és az Egyesült Államokban, hogy csak két nyilvánvaló példát vegyünk, bár a politikai tevékenységet nem övezik ilyen súlyos tiltások, a tudományos életen kívüli politikai mozgalmakban való részvétel - ehhez képest - nem gyakoribb, sőt talán ritkább is. Hogy lehet ez?

\section{A gyökerek}

A nemzetközi kritikai geográfia gyökerei egy egész generációnak az 1960-as években lezajlott, $s$ minden másnál nagyobb ihletet adó világméretü felkeléseiben és radikalizálódásában találhatók. A lázadások teremtette mozgalmak nagyon különbözőek voltak: marxizmus, feminizmus, fajgyülölet elleni és nemzeti felszabadí- 
Neil Smith : Jelszavak és könyörtelen kritika : Marxizmus és nemzetközi kritikai geográfia

Tér és Társadalom 17. évf. 2003/2. 37-51. p.

tási harcok, környezetvédelem, antiimperializmus, a homoszexuálisok, illetve leszbikusok jogai, a diákjogok, hogy csak néhányat említsünk. Ahogy ezek és az utánuk következó politikai küzdelmek elcsitultak, sok aktivista bekerült az egyetemek, illetve a tudomány világába, ahol a választás lehetösége adott volt: folytathatták a harcokban megnyílt radikális lehetőségek feltárását. E folyamat részeként kialakították a társadalomtudományi és bölcsészeti kutatási programok új élvonalát. Az átalakulás a geográfiában volt a legmeghökkentőbb: a legtöbb országban (Japán az egyik kivétel: Mizuoka 2000) a földrajztudománynak semmilyen, vagy nagyon csekély, támaszul szolgáló radikális történeti elözménye volt. Miért van az, tette fel a kérdést Blanca Ramírez (2000), hogy a geográfia olyan konzervatív? A radikálisok professzionalizálódása a legkorábban Nagy-Britanniában, Észak-Amerikában és Óceánia térségében ment végbe az 1970-es évektől kezdődően - a radikális geográfia harminc évére emlékezö visszatekintésekben ez központi téma volt². A folyamat Latin-Amerikában és Európában, főleg Dél-Európában teljesedett ki leginkább; később, az 1990-es években pedig Dél-Koreában és Dél-Afrikában. Azok a kelet-európaiak, akiket az 1960-as évek lázadásai inspiráltak, fontos szerepet játszottak az 1981 utáni (lengyelországi), és az 1989 és 1991 közötti népfelkelésekben, ám professzionalizálódásuk az 1990-es években gyorsult fel. A neoliberalizmus szétáradása az 1990-es években segített lezárni a folyamatot ott, ahol már elkezdődött, vagy elindítani, ahol még nem.

De van egy másik, párhuzamos, ezzel összefüggő történeti múlt is. Nagy tévedés volna, ha politikai küzdelmektöl mentesnek mutatnánk be a helyzetet. 1999 áprilisában az Universidad National Autonoma de Mexico (UNAM) hallgatói, akiknek létszáma 268 ezer, sztrájkba léptek. (Valójában ez azon a napon kezdödött, amikorra a Nemzetközi Kritikai Geográfiai Csoport döntéshozó testületének ülését idözítettük, tehát néhányan közvetlen közelröl lehettünk tanúi az események kezdetének, s nagy sietve izgalmas, tiltakozó előadássorozattá alakítottuk át a tervezett ülést. A többiek átélték az egész sztrájkot.) A legégetőbb kérdések egyike az egyetemi tandíj bevezetése volt, de a háttérben ott rejtőzködött a mostanra legyőzött PRI-kormány korrupciója és a zapatista küzdelem is. Még ennél is fontosabb, hogy az egyetemisták világosan érzékelték: a tandíj az első jele volt a kiterjedt neoliberalizmus behatolásának a felsỏoktatásba. Ahogy a saját egyetemem, a City University of New York (CUNY) diákjai egyértelmüvé tették: az UNAM harca azonos a CUNY-éval.

Vagy itt a dél-koreai eset. Az 1980-as évek diákmozgalmai élen jártak annak az ellenállási mozgalomnak a létrehozásában, amely az Egyesült Államok támogatását maga mögött tudó diktatúrát megbuktatta. Ezek a mozgalmak továbbra is jelentős, bár szórványos fenyegetést jelentettek a kormánynak, még a Demokrata Liberális Pártnak is. A dél-koreai kollegák nyilván meg tudják mondani, mennyire maradtak erősek a kapcsolataik a szervezett szakszervezeteken belül, amelyek erejéről meggyőződhettünk két hónapja, amikor a szöuli rendőrség rátámadt a szállodaipari alkalmazottakra. További, még váratlanabb helyeken a diákok is egyre jobban aktivizálódnak. A munkásszervezỏdés szintje az USA-ban az elmúlt két évben általában magasabb volt, mint bármikor az elmúlt negyedszázad során. Ennek oka - 
Neil Smith : Jelszavak és könyörtelen kritika : Marxizmus és nemzetközi kritikai geográfia Tér és Társadalom 17. évf. 2003/2. 37-51. p.

részben - a tagszervezetek szándékos törekvése, amelyet időnként a kevésbé konzervatív szakszervezeti vezetök is támogatnak, hogy aktívan betoborozzák a diákokat a szakszervezetekbe. A ,rabszolgahajcsár” foglalkoztatás elleni, a Nike-t bojkottáló és a tisztességes fizetésért folytatott kampányok száma megnőtt, melynek eredményeként a szakszervezetek és az egyetemi campusok közötti politikai kapcsolatok új, erösödő változata alakult ki (Merrifield 2000).

A radikális politika intézményesülésének azonban megvolt a maga hatása: jó is, rossz is. Sok helyütt tette lehetővé az 1980-as és 90-es években, hogy a radikális eszmék tovább éljenek, söt kibontakozzanak és felfussanak tudományos körökben is - ennek azonban gyakran éppen az öket mozgató és lendületben tartó politikai mozgalmaktól való különválás volt az ára. A kritikai geográfia ezen intézményesülés ellenreakciójaként lépett fel, ugyanakkor - legyünk öszinték - annak kifejeződéseként is. Az angol-amerikai világban a kritikai geográfia természetesen védelmet is jelent egy technokratább, neoliberális geográfia ellen, amelynek élére vagy azok álltak, akiknek minden reménye a GIS (Földrajzi Információs Rendszer), a tudományág intellektuális jelképe, vagy az, amit az Amerikai Geográfusok Társasága üzleti geográfiának nevez.

A kritikai geográfia kiterjedtsége és eklekticizmusa egyben az egyik erössége is. Gyökereit tekintve nyilvánvalóan befogadó projekt. Úgy tünik, mindent befogad, ami kívül esik a neoliberalizmus érdekszféráján: a posztstrukturalizmust, a posztmodernizmust, a marxizmust, a feminizmust, a fajgyülölet elleni munkákat, a homoszexualitás politikai nézetrendszerét, a "nem igazodó” társadalomelméletet, a környezetvédelem elméleteit, az antiimperializmust, a posztfordista gazdaságföldrajzot, az identitáspolitikai nézeteket, az új kulturális geográfiát és így tovább. Ahelyett, hogy azt a kérdést tennénk fel, mi a kritikai geográfia, sokkal határozottabb (és rövidebb) választ kapunk arra a kérdésre, hogy mi nem az, és mit zár ki. Azonban a Nemzetközi Kritikai Geográfia 1997-es vancouveri alakuló konferenciáját követően, Graciela Uribe-Ortega úgy érvelt, hogy ha mindent kritikai geográfiának lehet nevezni, akkor abból semmi sem lesz (idézi Katz 1998; Castree 2000).

Úgy vélem, ez a legfontosabb dilemma, amellyel ma szemben találjuk magunkat. Nem annyira arról van szó, hogy egy pontosan meghatározott kritikai hagyomány körül kell meghúzni a határt, mint inkább arról, hogy meg kell határozni és segíteni kell azt az elméleti és gyakorlati magot, amely meghatározza a kritikai geográfiát. Ez kétségkívül a legfontosabb különbségtétel. Ha nem tudunk megegyezni a nemzetközi kritikai geográfia központi céljaiban, akkor, ha lehet is valamilyen erỏ a birtokunkban, az szertefoszlik.

\section{Jelszavak}

Sok, mostanában lezajlott beszélgetés és esemény segített a következőkben bemutatott nézeteim kialakításában. Hadd említsek meg hármat közülük! Mindegyik angol anyanyelvü geográfusokat érint, akik szívesen fogadták vagy fogadnák el a „kritikus” címkét. Az első beszélgetésben egy húszas éveiben járó egyetemistát 
Neil Smith : Jelszavak és könyörtelen kritika : Marxizmus és nemzetközi kritikai geográfia

Tér és Társadalom 17. évf. 2003/2. 37-51. p.

kérdeztem meg, mi a kutatási témája, amikor a társalgás átváltott a posztstrukturalizmusra és Foucaultra. Megkérdeztem, miért Foucault a megfelelö elméleti kerete a kérdéses problémának. Sok bizonytalankodás után azt a választ kaptam, hogy „bármi, csak ne az az elavult marxista dolog" legyen. A poén valószínủleg nyilvánvaló, ám néhány percnyi beszélgetés után jött a hetyke beismerés, hogy valójában sohasem olvasott Marxot.

A második egy geográfiatörténeti egyetemi órám után történt. Előadásomban megpróbáltam értelmezni az amerikai imperializmus kritikáját egy neves konzervatív amerikai geográfus, Isaiah Bowman pályája segítségével, aki Woodrow Wilson és Franklin Roosevelt tanácsadója volt (általában a világ háború utáni újjászervezését illetően), és aki egyébként 1917 és 1950 között az amerikai kormány alkalmazásában állt. Egy doktorandusz hallgatóm kérdésekkel bombázott az idézett munka feminista tartalma után érdeklődve. Mivel a szóban forgó írás annak a kỏnyvnek a kéziratából való, amellyel már két évtizede küszködöm, valószínúleg kissé érzékeny voltam; ám amikor azt válaszoltam, hogy az valójában nem egy feminista történet, kioktatott, hogy az ilyen történetírásnak ma már nincs legitimitása. Ez heves politikai vitát robbantott ki, amely több helyszínen és több napig tartott. Igazi dőbbenetemre ugyanaz a kritikus, amikor később a kulturális tanulmányok tényleges politikai tartalmát vontam kétségbe, azt válaszolta, hogy sem saját feminizmusát, sem kulturális földrajzi kutatását nem tekinti politikai vonatkozásúnak.

A harmadik eset egy magasabb beosztású amerikai társadalomföldrajzprofesszorral kapcsolatos, aki - miközben arról panaszkodott, milyen komiszul bántak vele bizonyos kézirat-recenzensek, miután egy tanulmányát elküldte közlésre -, egyenlőségjelet húzott a személyét és elgondolásait ért ,intellektuális támadás” és a nők elleni, valamint a szerbiai etnikai tisztogatásban megnyilvánuló erőszak között.

Mindegyik eset és beszélgetés ráébresztett az általunk ma kritikainak nevezett geográfia különféle gyengeségeire. Az első esetben Marx nem ismerete az érem egyik oldala, amelyet maga Foucault természetesen soha sem türt volna meg; azonban egy ennyire fontos politikai gondolkodó dacos nem ismerete legalábbis mủveletlenség, de lehet, hogy kóros is. Öszintén megvallva azonban ezért a tudomány mủvelőit - beleértve magamat is - terheli a felelösség, hiszen a posztstrukturalizmus, posztmodernizmus és a tágabb értelemben vett társadalomelmélet mámoros időszakában ellustultunk: nem fordítottunk kellő időt Marx tanítására, mert feltételeztukk, hogy diákjaink már ismerik. Nem ismerték. És ma már nagyon kevesen ismerik. Azonban ez is változik.

A második esetben nem az a meglehetősen leszükítỏ elvárás aggasztott igazán, hogy ma már minden geográfia-történetnek feministának kell lennie, hanem az a sokkal károsabb feltételezés, hogy a feminista kulturális geográfiának nem sok köze van a politikához. A harmadik történet megértette velem, hogy az angol-amerikai kritikai geográfia nagy részében ma úgy járunk el, mintha minden küzdelem erkölcsileg egyenértékü lenne. Azonban nincs semmiféle egyenlöség - sem morális, sem politikai - egy elit professzor „firkálmányait” lehúzó kritika és a brutális nemi erőszak vagy az etnikai tisztogatás nevében elkövetett kínzás és tömeggyilkosság között. 
Neil Smith : Jelszavak és könyörtelen kritika : Marxizmus és nemzetközi kritikai geográfia Tér és Társadalom 17. évf. 2003/2. 37-51. p.

Az elmúlt két évtizedben észrevétlenül egy sor jelszó uralta az általunk „kritikainak" nevezett geográfiát. (Ez a kritika is föleg, s talán kizárólag az angol-amerikai geográfiára vonatkozik, s elnézést kérek, ha ennek az érvelésnek a helyhez kötöttsége sokak számára magát a vitát teszi érdektelenné. Egyetlen mentségem, hogy jelentös figyelem irányul a világ ezen részének történéseire, s szükségét érzem, hogy jelezzem elhatárolódásomat.) A jelszavak divatos szólamok, közhelyek, mélyen gyökerezö vélekedések, amelyek megkülönböztetik az egyes csoportokat, amelyekröl azonban az is kiderülhet, hogy üresek. Érinthetetlen igazságoknak képzelik öket. A nemzetközi kritikai geográfia markánsabb definiálására való ösztönzésünk eszközeként szeretnék véleményt füzni öt jelszóhoz, melyek - véleményem szerint - ma az angol nyelvű közegben íródott „kritikai” geográfia nagy részét jellemzik: befogadás, reflexivitás, a harcok egyenértékủsége, egyenlőségjel a politika és az etika között, valamint a ,rések politikája”.

1) Befogadás: Az 1960-as évek küzdelmeiböl fakadó legerőteljesebb politikai követelések némelyike a képviselet és a befogadás kérdése körül forgott. A tüneteket tekintve s a „tér nyelvén” szólva az érvelés úgy szólt, hogy a nök, a faji és etnikai kisebbségek, a diákok, a homoszexuális férfiak és leszbikus nők ezen identitásuk alapján marginalizáltak, képviselet nélkül maradnak, vagy ki vannak zárva a társadalom látóköréből és a politikai hatalomból. A kizsákmányoltak és elnyomottak mozgósításának eszközeként, - hogy olyan politikai cselekvésre ösztönözzön, amelynek célja azoknak a társadalmi és politikai hatalmi viszonyoknak a megdöntése vagy legalábbis gyökeres reformja, amelyek fenntartották ezt a kirekesztést ezek a követelések dinamizálták az idöszak legeröteljesebb, legradikálisabb és az egymással legjobban összekapcsolódó politikai mozgalmait, és sok helyütt jelentős jogokat harcoltak ki a marginalizáltaknak. Amikor azonban a befogadás/kirekesztés kérdését „identitáspolitikává” általánosítva teoretikai alapelv szintjére emelik, s főleg amikor azt a „másság” hiányzó hangját hangsúlyozó bizonyos fajta posztstrukturális elméletekbe ültetik át, akkor vele a nem, az osztály, a faj stb. társadalmi viszonyaiban gyökerezó termelés, társadalmi újratermelés és hatalom struktúráinak az elemzését helyettesítik. A befogadás követelménye olyannyira automatikussá vált, hogy már meg sem kérdezzük: befogadás mibe? A befogadás nyelvezete mobilizálható és ügyesen mobilizálták is a globalizáció összefüggésrendszerében. A szabad kereskedelem védelmezői - a Világkereskedelmi Szervezettől kezdve a Világbankig - a szabad kereskedelem előtti idószak kapitalista jólétéböl korábban kizárt országok befogadásának hajtóerejeként dicsőítik a globalizációt. Kína követeli a „,befogadást”. A Világkereskedelmi Szervezet félbeszakított seattle-i találkozóján Clinton elnök önérdekböl támogatta a konzervatívabb szakszervezeti és környezetvédő képviselök követeléseit, hogy vonják be őket a szabad kereskedelemre vonatkozó döntéshozatalba, hogy „,helyet kapjanak az asztalnál”. „Centrista” és „,befogadó” voltak a kulcskifejezések, amelyek a republikánus platformot jellemezték a legutóbbi philadelphiai fiaskón.

A befogadás/kirekesztés kategóriája mára már kiüresedett, amennyiben minden, illetve bármilyen ügy érdekében lehet mozgósítani, és mozgósítanak is. A neolibe- 
Neil Smith : Jelszavak és könyörtelen kritika : Marxizmus és nemzetközi kritikai geográfia

Tér és Társadalom 17. évf. 2003/2. 37-51. p.

rális globalizáció teljességgel kisajátítja magának. Mindenkiben van valamiféle másság, a „befogadás” ma már inkább technokrata, mint radikális követelés. A befogadás követeléséböl kiürült minden maradék radikális tartalom, amelyet csak úgy lehet pótolni, ha komoly eröfeszítéssel megpróbálunk választ adni a kérdésre: „Befogadás mibe?" Mert ma sokan vagyunk, akik nem akarunk részévé válni a módszeresen kizsákmányoló és elnyomó intézményeknek. Henri Lefebvre (1991) más összefüggésben mondott szavaival élve: fel akarjuk robbantani a dolgok jelenlegi állását.

2) Reflexivitás: A befogadás követeléséhez hasonlóan, a reflexivitáshoz való ragaszkodás - teljes mértékben beleértve saját helyzetünket a hatalom társadalmi rendszereiben - lényegre törő politikai szerepet játszott az 1960-as éveket követö új politikai mozgalmak megjelenésében. A nemi elnyomás megrögzött továbbélése a diák- és szocialista mozgalmakban, a faji kirekesztés ismétlödése a feminista mozgalmakban, vagy az osztályjelleg jelentkezése a leszbikus és homoszexuális mozgalmakban mind az aktivisták összejátszásának erôteljes érzését gyorsították fel, és azt az igényt erősítették, hogy a kritikai önvizsgálatot tettekkel kapcsolják össze. A reflexivitáshoz való radikális ragaszkodás, - amit kiegészítenek a társadalomtudományok álobjektivitásának kritikái, befolyásolnak a pszichoanalitikai elméletek, és finoman átalakít az identitáspolitika és a kulturális elméletek elhatárolódása a politikai küzdelmektöl - kifelé irányuló eröböl befelé forduló korlátozássá változott át. A követelmény, hogy tudatos szereplöi legyünk a harcnak, amelyben részt veszünk, unalmas kötelességgé puhult, mégpedig, hogy helyezzük el saját magunkat diskurzusainkban. A jámbor gyónás - amely elöször is nem szükségszerủen jó módszer megnyitja a kapukat az önmagunkkal való megszállott foglalkozás elött. A reflexivitás ma valószínúleg inkább szítja - bár ki nem mondottan -, mint konfrontálja a nyugati kapitalista társadalmak liberális individualizmusát. Egy Leibnizre emlékeztetö, váratlan idealista fordulattal élve azzal is lehet érvelni, hogy önmagunkat megérteni egyenlö a világ megértésével. Bob Fitch $(1989,19)$ New York-i szakszervezeti szervező és író 1989-ben arról panaszkodott, hogy ,a baloldal új politikai nyelvtant teremtett. Megváltozott a politikai alany. Már nem beszélnek a tömegekröl, a munkásokról, az emberekről - róluk. Manapság már a 'mi' használatos. A baloldali értelmiség lett a politikai tevékenység alanya. A mi gondjaink. Nem az övék."

3) A küzdelmek egyenértéküsége: A „kritikai" politika 1980-as évektöl kezdödö újrafókuszálása a befogadás és az identitás kérdései irányába érzékelhető eredményeket hozott. Sohasem túl mélyen a felszín alatt feszült alkudozás (sőt harc?) folyt az elkülönült identitások között, melyek mindegyike képviseletért vetélkedett, $\mathrm{s}$ azért, hogy joga legyen szólni az elnyomásról. Elterjedt a Brackette Williams (1993) metsző kritikájával „az üldöztetés versengő moralizmusának” nevezett jelenség: a különböző identitás-alanyok az üldöztetés mértékén és súlyosságán alapuló politikai hatalomért versenyeznek. Azáltal, hogy a társadalmi újratermelés, a faji hatalom, az osztályviszonyok vagy az állam társadalmi strukturálódásának elemzései (szemben a kifejeződésével vagy megtapasztalásával) divatjamúltakká váltak, az identitások deklarált ekvivalenciája (a fekete bőrü nem jobb, s nem rosszabb a fehér 
Neil Smith : Jelszavak és könyörtelen kritika : Marxizmus és nemzetközi kritikai geográfia Tér és Társadalom 17. évf. 2003/2. 37-51. p.

bőrủnél, a homoszexuális nem jobb, s nem rosszabb a heteroszexuálisnál stb., csak más) lassanként az identitásra épülö harcok ekvivalenciájává változott át. A kulturális tanulmányok és az identitáspolitika nyelvében a tér megjelenítése - a kizsákmányolás, az elnyomás vagy az alávetettség feladása a kirekesztés és a marginalizálás kedveért - oly módon támogatta a harcok ezen kialkudott ekvivalenciáját, hogy, akaratlanul is a faj, a nem vagy például a szexualitás által meghatározott elkülönült „terekként" kezdte megerősíteni az identitásokat, ahelyett, hogy meghaladta volna azokat (Katz-Smith 1993). Csakhogy e harcok nyilvánvalóan nem egyenértékủek.

4) A politika összekeverése a morális elkötelezettséggel: Minden politika része a morális elkötelezettség, azonban csak a liberális idealista politika véli úgy, hogy a morális elkötelezettség azonos a politikával. A politika szétesése morális vagy etikai kérdéssé változatos módon fejeződik ki: a „sokféleség” ügye felé való fordulástól a liberális multikulturalizmusig terjed (nem szabad elfelejtenünk, hogy a Szöulban tartandó igen konzervatív Nemzetközi Geográfiai Kongresszus témája is a „sokféleség” lesz ${ }^{3}$ ). Habár mindezek miatt a politika összekeverése a moralitással az identitáspolitikával is összefügg, de visszavezethető a környezetvédö politika és az állatvédő mozgalmak hatására is, amelyek nagyrészt - ha nem teljes egészükben - erkölcsi felhívásokra építenek (lásd pl. Slaok-Whitt 1992; Champagne 1995). Amint a Nemzetközi Kritikai Geográfiai Konferenciát követő vitából is kiderült, ez a zavar áthatja a kritikai földrajzot, $s$ makacsul tartja magát. Ezért az itt felvázolt kritikával egyébként egyetértó cikkében egy kritikai geográfus, miközben számba veszi a politikai aktivizmus különféle típusait, idesorolja a jótékonysági tevékenységet is ${ }^{4}$ (Castree 2000). A jótékonykodás jó dolog lehet, s bizonyára a filantrópiához is köthetö egy (gyakran messze nem haladó) politikai nézetrendszer, ám a jótékonyságot aligha tanácsos összetéveszteni a politikai változással. Ezzel ellentétben Marx úgy szőtte bele társadalometikáját a kapitalizmus elleni kritikai vádiratába, hogy a politikai kritika kifejezze a tiszta moralitást, de ne az mozgassa.

5) A rések politikája: A társadalomeimélettel foglalkozókat, - akik erósen buzgólkodnak annak a definíciónak a kiterjesztésén, hogy mi számít politikának, miközben ugyanakkor igyekeznek kikerülni a létezó politikai alternatívákat - az 1970-es évek óta a posztstrukturalizmus inspirálja, föleg a foucault-i eredmények, amelyeket „politika a társadalmi élet réseiben” elnevezéssel lehetne illetni. Amit Benjamin a lehetőség nyomvonalaként szemlélt, - az ismétlődő mindennapi cselekedetek utánzásában bekövetkező változás lehetösége - az 1980-as és 90-es években a politika elsódleges, ha nem kizárólagos helyeként nyílt meg. A rések politikája egy alternatíva lett, inkább menekülési útvonal a politikai felépítmény hagyományosabb formáitól, mint azok kiigazítója. A politikai textusok elhallgatásainak és kihagyásainak diszkurzív azonosítását felértékelve, megerősített egy idealista fordulatot, de közben párhuzamosan azt is hangsúlyozva, hogy összefüggés van az ilyen ábrázolások kritikája és a mindennapi életben fellelhető ellenállás mindenhol jelenlevősége között. Nem az a lényeg, hogy önmagában téves volt kiterjeszteni, mi számít politikának; inkább az, hogy még az eróteljesebben megalapozott formákban is, amilyen „az ellenállás mindennapi formáinak” James Scotts-i meghatározása, az 
ellenállás megjövendölése a mindennapi élet „felvillanásaiból” és „ujjcsettintéseiből" a cselekvőképességet erősen individualista társadalmi erővé változtatta. Ez pedig logikus módon ahhoz a kérdéshez vezetett, hogy mitöl lettek a szubjektumok politikaiak (mi a „szubjektumformálás politikája”), az angol-amerikai világban pedig reflektorfénybe helyezödött, hogyan járul hozzá a fogyasztás (a termelési viszonyoktól határozottan megkülönböztetve) az identitások megteremtéséhez. Ma ott tartunk, hogy a szubjektivitás kulturális kialakításáról szóló munkák zöme elveszítette valamennyi egyértelmú kapcsolatát mindazokkal a politikai programokkal, amelyekkel kezdetben összeköttetésben állt. Röviden: egyre inkább csak egy skolasztikus gyakorlat. Gavin Smith (1999) antropológus Scottról szóló eröteljes és egyértelmú kritikájában úgy érvel, hogy a rések politikájának felemelése a politikai taktika szintjére, miközben a kizsákmányolás és elnyomás szerkezete és rendszere tovább él, valójában megerösíti a szabályozás rendszerét.

Ez az öt különálló, mégis összefüggő jelszó eröteljesen müködik a kritikai geográfiában, föleg angol nyelvŭ változataiban. Kölcsönösen erösítik egymást az úgynevezett „,kritikai politika” kialakításában, amely valójában nem jelent nagy veszélyt a globális hatalmak - a kapitalizmus, a patriarchátus, a fajgyülölet és az imperializmus - fennálló szerkezetére és kapcsolataira. Inkább úgy tünik, hogy - ellentétben a különféle mozgalmakkal, amelyek nemzették öket - implicite egyfajta (elö- vagy neo-) liberalizmushoz (valamint individualizmushoz és idealizmushoz) visznek vissza, amely messze van attól, hogy megegyezzék azzal a neoliberalizmussal - sőt, még igazoló ellenzéki interpretációval is el tudná azt látni -, amely a jelenkori globalizáció forgatókönyvét írja. Továbbá, amennyiben a hangsúly a látszólag egyenrangú szereplők és harcok „befogadásán” van, és a cselekvőképesség kikerül az elnyomás társadalmi struktúráinak kontextusából, az új társadalmi konstrukcionizmus nagyrészt magától értetődőnek tekinti a társadalmi struktúrákat. Az 1980-as évek Nagy-Britanniájában a brit miniszterelnök, Margaret Thatcher híres kijelentése az volt, hogy ,a társadalom mint olyan nem létezik"; ma talán az a veszély fenyeget, hogy a rendszerhez tartozó társadalmi struktúrák és társadalmi viszonyok magától értetődőnek vétele valójában ennek az érvelésnek olyan haladónak látszó változatát csempészheti be, amely sokkal kompatibilisebb a neoliberalizmussal, bármit támogasson is erkölcsileg, mint például a kapitalizmus marxista kritikájával.

Gavin Smith $(1999,33)$ hasonló észrevételt tesz. Ami ma „kulturális kritikaként” fut, veti fel, „sokkal kényelmesebben beágyazódott a befogadás/kirekesztés diszkurzusába egy [olyan] társadalom képével együtt, [mint] ... amely ellenében vagy amelyen túlhaladva egy felszabadító program eröforrásainak helye lehetne. Mivel a történelmileg azonosítható társadalmi formákhoz füződő dialektikus viszonyban nem manifesztálódik, a kifejezödést olyan tapasztalatokban keresi, amelyek ellenállnak a társadalomnak azáltal, hogy tagadják magát a társadalmit." 
Neil Smith : Jelszavak és könyörtelen kritika : Marxizmus és nemzetközi kritikai geográfia Tér és Társadalom 17. évf. 2003/2. 37-51. p.

TÉT XVII. évf. 2003 『 2

Jelszavak és könyörtelen kritika ...

47

\section{Marxizmus}

Jelen írás semmiképp sem vádbeszéd azok politikai motivációja ellen, akik a kritikai geográfiához hozzájáruló mozgalmak ernyője alatt gyülekeznek. A lényeg éppen az, hogy - ellentétben azzal, ami egy ilyen reakcióból következne - a jelen kritika sem nem individualista, sem nem liberális vitapont. Aligha meglepö, hogy az 1970-es évek óta erősödő konzervativizmus időszakában az ellenzékí társadalmi mozgalom magába szív valamennyit ebből a konzervativizmusból. A társadalmi és politikai kontextus hiánya az elméletben a társadalmi és politikai kontextus még nagyobb hiányát fejezi ki abban a környezetben, amelyben az elmélet létrejött. Ma tehát sürgető szükség van arra, hogy újra feltaláljuk ezeket a politikai mozgalmakat, és ismételten átitassuk őket a radikális szándékkal, amelyböl eredtek. Ehhez természetesen nemcsak az ábrázolások, textuális elhallgatások és diszkurzív termékenység kritikájára van szükség, hanem arra is, hogy úgy használjuk őket és más eszközöket, hogy elérjük azt, amit Gavin Smith (1999) „a történelmileg azonosítható társadalmi létformákhoz füződő dialektikus viszonynak" nevez. A ma céljait eszközként kell helyükre tenni. A társadalmi formációk, folyamatok és viszonyok elemzése - kifejeződésük révén vagy másképp - az elsődleges cél.

A marxizmust, más elméleti és gyakorlati kritikához hasonlóan, folyamatosan újra kell teremteni. A sztálinizmus társadalmi és politikai horror volt, amelyet annyira tudunk elkerülni a jövőben, amennyire - mindenekelőtt - megértjük, hogyan tudott egyáltalán megtörténni. Az osztálypolitika nem garancia arra, hogy egy társadalmi mozgalom ténylegesen megváltoztatja a világot. A konzervatív és a szük önérdek vezérelte szakszervezeti mozgalmak szerte a világon, s talán föleg az Egyesült Államokban, mostanáig egyértelmü bizonyítékai ennek. Ez azonban ugyanúgy nem jelenti azt, hogy az osztály felesleges, mint ahogyan a ,kulturális kritika" vagy a faji esszencializmus kritikája sem jelenti azt, hogy a kulturális politikát vagy a faji alapú politikát el kellene vetni.

Marx az osztály jelentősége mellett érvelt, mert - szerinte - a kapitalista gazdaságban az osztálykizsákmányolás az értéktöbblet-termelés társadalmi alapja, ezért a tỏkefelhalmozásé és a gazdasági újratermelésé is ${ }^{5}$. Különleges helyeken és időszakokban a munkásosztály magában foglalhat sokféle faji és etnikai csoportot, továbbá a férfiak és a nök sajátos kombinációját. Itt az a lényeg, hogy az osztály Marx szemében az első és legfontosabb társadalmi kategória. Bár a kapitalista társadalom sajátos gazdasági viszonyai hozzájárulnak a társadalmi és politikai viszonyok újratermeléséhez, és megerősítik öket, az osztályviszonyok mozgósítják a sajátos gazdasági viszonyokat, s nem fordítva. A társadalmi viszonyokat kell átalakítani, ha meg akarjuk nyitni a politikai gazdasági rendszert a változások elött. Itt a munkásosztály, amelynek rendszerint részei az elnyomott nemzetiségek, fajok, s a nök többsége is, - minden jelenkori társadalomban - az alapvető fontosságú összetevő, pontosan azért, mert, bár a gazdasági tranzakcióban a munkások árucikként adják el munkaerejüket, megtartják közvetlen társadalmi és politikai erejüket, részesei a kollektív munkamegtagadásnak, készen arra, hogy lerombolják a gazdasági rendszert, s 
Neil Smith : Jelszavak és könyörtelen kritika : Marxizmus és nemzetközi kritikai geográfia

Tér és Társadalom 17. évf. 2003/2. 37-51. p.

hogy kiprovokálják a lecserélését valami mással. A kizsákmányolás ezen rendszerének megdöntése csak a munkásosztálynak jelenti a közös jót. Ez olyan eredmény, amelyet a szorosan faji és nemi szempontú szolidaritás nem tud elérni, amennyiben ezek az érdekek gyökeresen ellentétes osztályérdekeket foglalnak magukban.

Ebböl az érvelésböl gyakran két leegyszerüsítő következtetést vonnak le. Elöször is, gyakori az a feltételezés, hogy az osztály a marxi elemzésben valamilyen módon filozófiailag vagy morálisan kitüntetett helyzetủ, vagy, hogy Marx romanticizálja a munkásosztályt. Ez az olvasat nemcsak téves, hanem jelzés értékủ is a leegyszerüsítéssel kapcsolatban, amelyet megpróbál elkerülni. Amennyire Marx kitüntetett szerepet ad az osztálynak és a munkásosztálynak mint a forradalmi változás kollektív szereplójének, az inkább politikai, mint erkölcsi vagy filozófiai megítélést jelent. A politika leredukálása a morálisra vagy a filozófiaira analitikai összeomlást jelent, amely emlékeztet a modern liberalizmusra - amint erröl meggyőződhettünk -; Marx viszont nem volt liberális. Másodszor: az is gyakori következtetés, hogy miután a forradalmi cselekvőerőt megtalálta a munkásosztályban, Marx az osztályt valami módon változatlannak, a társadalmi átalakulást pedig elkerülhetetlennek vélte, biztosra vette. Marxnak éppen ez az olvasata távolítja el a nem-osztály alapú cselekvőképességet a politikai színtérről: a forradalom feltartóztathatatlanul következik az osztálykategóriából. Azonban ennek az olvasatnak az idealizmusa is inkább a kortárs politikaelméletben és gyakorlatban, semmint Marx írásaiban keresendó. Ahogy még a Wall Street-i brókerek is készséggel elismerték a Kommunista Kiáltvány százỏtvenedik évfordulójának elỏestéjén: Marx globális elemzését drámaian visszaigazolta a globalizáció beköszönte (Cassidy 1997). Ez pedig arra utal, hogy bár mélyen alábecsülte a térbeliség viszonylagos tehetetlenségi nyomatékát (a tér idỏ általi megsemmisítésének megszokott problémája), mindazonáltal rendkívüli éleslátással értette meg a kapitalista fejlődés pályáját. Hasonló érvényes arra is, ahogyan az osztály fogalmát kezelte. Az osztályharcot övező optimizmusa saját történelmi kontextusából kiemelkedö „rúdugrásnak” tekinthetö. Viszonylag gyér figyelmet szentelt a politikai szervezet zavaros ügyének, de nem okos dolog ezt a hiányosságot, vagy akár a Szovjetunió mint munkásosztály-projekt nagy bukását (nem 1989-ben, hanem az 1920-as évek közepén) az osztály és az osztálypolitika elméleti tagadásának tekinteni.

Mondandóm zárásaként az eddig felvázolt kérdések közül úgy próbálok néhányat konkretizálni, hogy azok kapcsolódjanak a mostanában megjelenö globalizációellenes mozgalmakhoz. Vegyük a "Szabad Tibet” mozgalmat, amely az 1990-es években jelent meg, a Világkereskedelmi Szervezet elleni, 1999-es seattle-i utcai harcokat követően teljesedett ki, s vált e harc kiemelkedő szimbólumává. Ezt a mozgalmat, amely Tibet kínai gyámság alóli felszabadításáért küzd, több minden mozgatja: nemzeti és vallási identitás, liberális szocializmus-ellenesség és amerikai protekcionizmus. Ötvözi a világméretủ és nemzeti-helyi törekvéseket, amennyiben befolyásolja Kínának a globális kapitalista rendszerbe történő integrálódását, és kihat a globális gazdasági és kulturális változások pályájára is. Központi jelképei a szerzetesi ruhába öltözött tibeti szerzetesek és a dalai láma képmásai. 
Neil Smith : Jelszavak és könyörtelen kritika : Marxizmus és nemzetközi kritikai geográfia Tér és Társadalom 17. évf. 2003/2. 37-51. p.

TÉT XVII. évf. 2003 的 2

Jelszavak és könyörtelen kritika ...

49

Ez a mozgalom sokakat vonzott, akik a globálissal szemben a lokálisért, a diktatúrával szemben az emberi jogokért és Tibetnek a független demokráciák közé történö befogadásáért vívott harc élére állnak. Ami azt illeti, a „Szabad Tibet” mozgalom a mai kulturális kritika sok jelszavát egyesíti. A mozgalmat erösítő és/vagy kifejezö buddhizmus az önreflexivitás modellje, $s$ öntudatosan eröteljes kifejezödése a „rések politikájának” az én és a vallás vonatkozásában. Ebből közvetlenul következik, hogy a politika és a moralitás közé egyenlöségjel kerül. Bármennyire csodálatra méltó is, e mozgalom emberi jogi prioritása messze nem ,ártatlan”, mivel a hidegháborút követöen az emberi jogokból - inkább többé, mint kevésbé gazdasági és politikai fegyver lett (Koshy 1999). A Kína elleni nyugati kampány teljes egészében az emberi jogi diskurzus moralizmusát veszi át. De természetesen egy tekintélyelvü vallási monarchia nem lehet támogatható alternatívája a globális kapitalizmusnak (vagy államszocializmusnak). Az Egyesült Államokban a tibeti „lokalitásnak" nyújtott, a kínai önkényeskedés vagy a globális szabadpiacok elleni támogatást nagyrészt a Kína elleni fajgyülölettel keveredő szük nacionalista önérdek ösztönzi, melynek célja, megakadályozni, hogy az olcsó kínai munkaerő még közvetlenebbül legyen az amerikai tőke vetélytársa. A munkaerö értéke természetesen a társadalmi termelés és újratermelés kulcsfontosságú nexusa. Ebben az összefüggésben tekintve, az úgynevezett emberi jogi küzdelmek, a reflexivitás, a befogadás követelésének és a rések politikája nyílt támogatásának moralitása olyan nem ártatlan jelentéseket vesz fel, amelyek messze a tibeti-kínai nexuson túlról erednek. A neoliberalizmus nyelve segíti és szítja a tisztességes kereskedelem jellegzetesen amerikai programját, miközben univerzálisként tünteti fel magát.

Marx ugyanezzel a dilemmával találta szemben magát, jóllehet inkább az angol, mint az amerikai központú globalizációval kapcsolatban: hogyan lehet szembeszállni a szabad kereskedelemmel úgy, hogy egyidejüleg elkerüljük a szük nacionalizmust? Az angol gabonatörvények visszavonását követö, 1848-ban született írásából kiderül, hogy Marxnak nem voltak illúziói a szabad kereskedelemröl. A kereskedelem szabadsága - mondta - a tőke szabadsága. A szabad kereskedelem nem a nemzetközi viszonyok kiegyenlítődéséhez vezet, amint azt a globalizációs ideológiák szakadatlanul ígérik, hanem az értéktöbbletet termelö munkások nagyobb kizsákmányolásához, az egyenlőtlen fejlödés fokozódásához. Ugyanakkor, ,,a protekcionista rendszer nem más, mint a nagyméretú ipar létrehozása az egyes országokban”, s ezáltal „a világpiactól való fưggővé tétele”. Ám a protekcionista rendszer konzervatív, szólt Marx érvelése, a szabad kereskedelem pedig romboló. Széttördeli a régi nemzeti hovatartozásokat, $\mathrm{s}$ a végletekig viszi a proletariátus és a burzsoázia közötti antagonizmust. Röviden: a szabad kereskedelem rendszere sietteti a társadalmi forradalmat. „Uraim, kizárólag ebben a forradalmi értelemben támogatom a szabad kereskedelmet." (Marx 1976, 465)

Másfél évszázaddal később a protekcionizmusnak ez a kritikája és a világos, kritikai internacionalizmushoz való ragaszkodás továbbra is friss alternatívát kínál a jellegzetesen kapitalista globalizációval szemben. Azt is remekül illusztrálja, mit tehet a marxizmus elmélete a kritikai politikáért. Inkább az ellentmondások össze- 
Neil Smith : Jelszavak és könyörtelen kritika : Marxizmus és nemzetközi kritikai geográfia

Tér és Társadalom 17. évf. 2003/2. 37-51. p.

békítésére kínál lehetőséget, mint megbénul tölük: Marx ellenzi a szabad kereskedelmet, de a protekcionizmust még annál is jobban. Rámutat arra a pusztító lényegre, amit ma globalizációnak hívnánk, és fỏként annak az új internacionalista politikának a lehetőségére, amelyet megnyit. Ennek a politikának nemcsak földrajzi, hanem társadalmi értelemben is internacionalistának kell lennie. A radikális feminizmus, fajgyúlölet-ellenesség és antiimperialista politikák központi gondolatából éppen ezért eróteljes analitikai kritikákat tudunk a felszínre hozni, amelyek elénk tárják az elnyomás ezen formáinak rendszerjellegét. Ezek nem a kapitalizmus osztálykritikájával szemben ellenségesek, de a radikalizmusuk - mint az osztálypolitika radikalizmusa - függ attól, mennyire hajlandók elfogadni a kritikát. A neoliberalizmussal összhangban álló mérsékelt reformokról prédikáló szocializmus - Blair Nagy-Britanniájára, a ,harmadik útra”, és a német politikában Schröderre gondolok - nem különb válasz, mint a középosztálybeli nők szakmai érdeklődése felé orientált feminizmus. A politikai internacionalizmus összekovácsolása nem a kikristályosodott identitások közötti verseny, hanem sokkal egyszerübb és sokkal gyakorlatiasabb kérdés: hatékony politikai mozgalmak létrehozása, amelyek vonzzák és magukba szívják a munkásosztály életének élményét, és ösztönzést merítenek belöle. Oly sok a tennivaló, és már oly sok ember tevékenykedik. Ami a globalizáció ellenes mozgalmat illeti, - hogy csak egy példát említsek - az amerikai bérek világméretü elterjedésének követelésénél aligha tudnánk jobb kezdetet elképzelni.

Fordította: Miskolczy Lászlóné - Timár Judit

Jegyzetek

1 Jelen cikk a szerzỏ 2. Nemzetközi Kritikai Geográfiai Konferencián (2000. augusztus 9-13. Taegu, Korea) elhangzott előadásának anyaga. Elsö, angol nyelvü változata a konferencia kötetében jelent meg: Smith, N. (2000) Of Shibboleths and Ruthless Critique: Marxism and International Critical Geography - $2^{\text {nd }}$ International Critical Geography Conference - Taegu. For Alternative $21^{\text {st }}$ Century Geographies. Korean Association of Spatial Environmental Research. (Vol. 2), Taegu. 41-52. o.

${ }^{2} \mathrm{Az}$ angol-amerikai világban erre vonatkozóan lásd az Environment and Planning A 32, (6) 2000. tematikus számát, különösen Noel Castree, Ron Johnston és Neil Smith írásait.

${ }^{3}$ Lásd erről Katharyne Mitchell (1993) korábban írt briliáns kritikáját.

${ }^{4}$ A Nemzetközi Kritikai Geográfiai Konferencia moralitásról és etikáról szóló vitáját pedig lásd Katz 1998.

${ }^{5}$ Erröl a kérdésröl lásd részletesebben korábbi munkámat (Smith, N. 2000), melyből a következő bekezdések származnak.

\section{Irodalom}

Cassidy, J. (1997) The return of Marx. - New Yorker. 20 and 27 October. 248-259. o.

Castree, N. (2000) Professionalisation, activism and the university: whither "critical geography"? Environment and Planning A. 6. 955-970. o.

Champagne, J. (1995) Ethics of Marginality. A New Approach to Gay Studies. University of Minnesota, Minneapolis.

Fitch, B. (1989) What's left to write? Media mavericks lose their touch. - Village Voice Supplement. May 19. 19. o. 
Neil Smith : Jelszavak és könyörtelen kritika : Marxizmus és nemzetközi kritikai geográfia Tér és Társadalom 17. évf. 2003/2. 37-51. p.

TÉT XVII. évf. 2003 - 2

Jelszavak és könyörtelen kritika ...

51

Johnston, R. (2000) Intellectual respectability and disciplinary transformation? Radical geography and the institutionalization of geography in the USA since 1945. - Environment and Planning A. 6. 971-990. o.

Katz, C. (1998) Lost and found in the posts: addressing critical human geography - Environment and Planning D: Society and Space. 16. 257-278. o.

Katz, C.-Smith, N. (1993) Grounding Metaphor: Towards a Spatialized Politics. - Keith, M.-Pile, S. (eds). Place and the Politics of Identity. Routledge, London. 67-83. o.

Koshy, S. (1999) From cold war to trade war: neocolonialism and hu man rights. - Social Text. 58. 1-32. o.

Lefebvre. H. (1991) The Production of Space. Basil Blackwell, Oxford.

Marx, K. (1976) On the Question of Free Trade. Speech to the Democratic Association of Brussels at its public meeting of January 9, 1848. - Collected Works of Marx and Engels. Vol 6: 1845-1848. International Publishers, New York. 450-465. o.

Merrifield, A. (2000) The Urbanization of Labor: Living Wage Activism in the American City. - Social Text. 62. 31-54. o.

Mitchell, K. (1993) Multiculturalism, or the united colors of capitalism? - Antipode. 25. 263-294. o.

Mizuoka, F. (2000) A Tale of the Diverted Hare and Global Tortoise: the Tortured History of Critical Geography in Japan. $-2^{\text {nd }}$ International Critical Geography Conference - Taegu. For Alternative $21^{s t}$ Century Geographies. Korean Association of Spatial Environmental Research. (Vol, 1), Taegu. 224-239. o.

Ramírez, B. (2000) Why is Geography so Conservative? Social Practice at a lack of and Alternative Project in Mexico. - $2^{\text {"id }}$ International Critical Geography Conference - Taegu. For Alternative $2 I^{s /}$ Century Geographies. Korean Association of Spatial Environmental Research. (Vol. 1), Taegu. 21-29. o.

Slaok, J.D.-Whitt, L.A. (1992) Ethics and Cultural Studies. - Grossberg, L.-Nelson, C.-Treichler, P. (eds.) Cultural Studies. Routledge, New York. 571-592. o.

Smith, G. (1999) Confronting the present. Towards a politically engaged anthropology. Berg, Oxford

Smith, N. (2000) What happened to class? - Environment and Planning A. 6. 1011-1032. o.

Williams, B. (1993) The competitive moralisn of victimization. Unpublished lecture. Institute for Research on Women, New Brunswick NJ.

\section{OF SHIBBOLETHS AND RUTHLESS CRITIQUE: MARXISM AND INTERNATIONAL CRITICAL GEOGRAPHY}

\section{NEIL SMITH}

The rise of an international critical geography since the inaugural Vancouver conference in 1997 is both necessary and inspiring, but what counts as critical is very vaguely defined. As a means of trying to focus our understanding of what is critical about critical geography, I try in this to tackle some of the major shibboleths of this emerging political and intellectual grouping. It is now conventional wisdom on the left that we need to be inclusionary and selfreflexive, there is a sense that all political struggles are equivalent, and a confusion of politics with ethics, as well as a powerful place the most political of practices involves working not so much in movements but in the "interstices" of daily life. I challenge the usefulness of each of these arguments in the context of 21 st century international critical geography and conclude with an appeal that we rethink the power of the marxist critique through what we have learned from the critical engagement with these shibboleths. 